\title{
CASE COMMENT: ter NEUZEN v. KORN \\ AND THE STANDARD OF CARE: A CALL FOR CAUTION
}

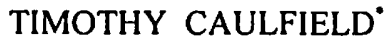

\section{INTRODUCTION}

Can professionals be found negligent even if their allegedly negligent actions conform with standards as established by expert testimony? More particularly, can a physician be found liable even though his/her actions are considered to be within the bounds of medical custom? The Supreme Court of Canada decision in ter Neuzen v. Korn has gone some distance in the clarification of this issue.' In short, the case has re-emphasized the principle that "when a doctor acts in accordance with a recognized and respectable practice of the profession, he or she will not be found to be negligent." ${ }^{\prime 2}$ More importantly, however, the case concluded that it is the medical experts, and not the judge or jury, who will establish the standard of care in relation to matters which concern "medical treatment or complex, scientific or highly technical matters." ${ }^{13}$

While for the majority of malpractice cases this approach makes eminent sense and is hardly controversial, the increasingly complex and multifactorial nature of health policy decisions may make the wholesale application of this principle to some cases such as those involving cost containment considerations - both inappropriate and potentially unfair to injured patient/plaintiffs. In this era of health reform, patient empowerment and economic restraint, technical medical considerations have become only one factor among many which impact final treatment decisions. ${ }^{4}$ As a result, if the strictly "medical" component of the treatment decisions cannot be severed from other considerations (such as economic exigency), and if the entire examination of the

- Research Director and Assistant Professor, Health Law Institute, Faculty of Law, University of Alberta. I would like to thank Gerald Robertson and Lewis Klar for their helpful comments.

1 (1995), 127 D.L.R. (4th) 577 (S.C.C.) [hereinafter ter Neuzen].

2 Ibid. at 590 . This is obviously not a new concept. See e.g. McDaniel v. Vancouver General Hospital, [1934] 4 D.L.R. 593, rev'g [1934] I D.L.R. 557 (P.C.) at 597: "A defendant charged with negligence can clear his feet if he shows that he has acted in accord with general and approved practice." See also L. Klar, Tort Law, 2d ed., (Toronto: Carswell, 1996) at 290; and E. Picard, Legal Liability of Doctors and Hospitals in Canada, 2d ed. (Toronto: Carswell, 1984) at 229. For a judicial statement on the medical standard of care see Crits v. Sylvester (1956), 1 D.L.R. (2d) 502 at 508 :

[A physician] is bound to exercise that degree of care and skill which could reasonably be expected of a normal, prudent practitioner of the same experience and standing....

3 ter Neuzen, ibid. at 595.

$4 \quad$ See e.g. G.R. Langley et al., "Effect of Nonmedical Factors on Family Physicians' Decisions About Referral for Consultation" (1992) 147 C.M.A.J. 659. For an in-depth discussion of the complexities of allocation decisions see E. Elhauge, "Allocating Health Care Morally" (1994) 82 Calif. L. Rev. 1449. See also P. Morrin, "Ethical Implications of Resource Allocation" (April, 1995) Ontario Medical Review 80; W. Stilling, "Who's In Charge: The Doctor or the Dollar" (1992) 18 Journal of Contemporary Law 285; and R. Evans, "Ethical Ambiguities and Economic Consequences in the Allocation of Health Care" (1993) Health Care, Ethics and Law 47. 
customary practice remains in the domain of only the medical expert, the ability of tort law to serve as a mechanism to monitor allocation decisions may be compromised. ${ }^{5}$

This case comment will examine this specific aspect of the ter Neuzen decision. ${ }^{6}$ That is, in this era of health care reform, will the trier of fact be foreclosed from finding that a given allocation policy is substandard because it is considered a facet of the overall medical decision? It seems unlikely that Sopinka J., who wrote for the majority, had any intention of narrowing the scope of inquiry in this manner. As we will see below, this case does not explicitly preclude judges and juries from scrutinizing the utilization or design of a relevant allocation policy (e.g., how physicians allocate diagnostic services, the use of expensive drugs, how waiting lists for surgery are formulated, etc.). However, given the traditional legal protections that are already enjoyed by the medical profession and the need (or perhaps the desire) to ensure that health care resources are distributed equitably, a cautionary comment calling for the careful application of ter Neuzen seems warranted.

\section{BACKGROUND}

In January, 1985, the plaintiff was infected with the HIV virus as a result of a process of artificial insemination (AI) which was performed by the defendant, Dr. Korn. ${ }^{7}$ At the time of the procedure the knowledge about HIV transmission was growing, however, the risks of infection from AI were not well established. Dr. Korn became aware of the potential AI risks when, in July, 1985, he heard about a number of Australian women who had contracted HIV through AI. At that time, the defendant stopped his AI program and recommended that all his AI participants be tested whereupon Ms. ter Neuzen discovered she was infected.

At trial expert evidence was presented that supported the conclusion that "the respondent's AI practice was in keeping with general practices across Canada. Specifically, his AI practice of recruitment and screening of donors and semen accorded with standard practice across Canada." ${ }^{18}$ Nevertheless, the trial judge instructed the jury that they could find the approved practice, as established by expert testimony, to be negligent. The jury found for the plaintiff - although it is unknown on what basis they came to the conclusion that Dr. Korn was negligent. The Court of Appeal ordered a

I have examined the use of tort law as a mechanism to protect patients' interest elsewhere. See, e.g. T. Caulfield, "Health Care Reform: Can Tort Law Meet the Challenge?" (1994) 32 Alta. L. Rev. 685. See also Canadian Bar Association Task Force on Health Care, What's Law Got To Do With It? (Ottawa: Canadian Bar Association, 1994); and E. H. Morreim, Balancing Act: The New Medical Ethics of Medicine's New Economics (Washington: Georgetown University Press, 1995). It should be noted that this decision addressed a number of other important issues such as medical product liability. On product liability see also Hollis v. Dow Corning Corp. (1996), 129 D.L.R. (4th) 609 (S.C.C) [hereinafter Hollis]. See B. Windwick, "Recent Decisions" (1994) 4 Health Law Review 23-26, for a brief review of both Hollis and ter Neuzen. 
new trial on the issues of liability and damages. ${ }^{9}$ Ms. ter Nuezen appealed that decision.

\section{ANALYSIS}

\section{A. DISTINGUISHING BETWEEN TECHNICAL MEDICAL DECISIONS AND ALLOCATION POLICY}

The focus of Sopinka's standard of care analysis was whether - given conclusive expert evidence - a judge or jury could disregard the generally approved practice and, in effect, "decide that the general practice itself was negligent." ${ }^{10} \mathrm{He}$ held that, in general, they could not. This conclusion was based largely on the belief that in complex technical areas judges and juries are not capable of making an informed decision regarding the appropriate standard of care. The only exception to this rule is when the matter at issue is one which falls in the realm of common sense - "where the common practice is fraught with danger, a judge or a jury may find that the practice is itself negligent."'I This general principle is summarized by Sopinka J. as follows:

I conclude from the foregoing that, as a general rule, where a procedure involves difficult or uncertain questions of medical treatment or complex, scientific or highly technical matters that are beyond the ordinary experience and understanding of a judge or jury, it will not be open to find a standard medical practice negligent. On the other hand, as an exception to the general rule, if a standard practice fails to adopt obvious and reasonable precautions which are readily apparent to the ordinary finder of fact, then it is no excuse for a practitioner to claim that he or she was merely conforming to such a negligent common practice. ${ }^{12}$

Although the ter Neuzen decision has clarified the law in this area, it is actually quite consistent with the past few cases where the courts have found that the approved practice was negligent. For example, in the influential case of Anderson v. Chasney, ${ }^{13}$ which Sopinka J. cites with approval, a physician left a sponge in a child's throat after surgery. Evidence was led that it was not the standard practice of the hospital to count the sponges used or to use sponges with strings on them. The court held that this was a matter which "an ordinary man is competent to consider in arriving at a decision as

$9 \quad$ ter Neuzen v. Korn (1993), 103 D.L.R. (4th) 473.

10 Klar, supra note 2 at 290 . It should be noted that the Court also concluded that "in the context of this case, the conduct of the physicians must be judged in the light of the knowledge that ought to have been reasonably possessed at the time of the alleged act of negligence," ter Neuzen, supra note 1 at 589 .

11 ter Neuzen, ibid. at 592.

$12 \quad$ lbid. at 595.

13 (1949), 4 D.L.R. 71, aff d (1950) 4 D.L.R. 223 (S.C.C.) [hereinafter Anderson]. See also Hajgato v. London Health Assn. (1982), 36 O.R. (2d) 669 at 693 (H.C.), aff d (1983), 44 O.R. (2d) 264; and Pittman Estate v. Bain (1994), 112 D.L.R. 257 (Ont. Ct. Gen. Div.) at 314:

A court will accept the reputable body of opinion of standard, if the subject matter is a technical medical or scientific one. But if the subject matter of the differing opinions is based on common sense, rather than on professional skill and specialized knowledge, then a court is entitled to ignore the opinions of medical and scientific experts and set its own standard of care. 
to whether or not there was negligence." 14 Indeed, Sopinka J. concludes that the situation presented in Anderson was one which "involved no difficult of uncertain questions of medical or surgical treatment nor any matter of a scientific or highly technical character."1s

In the vast majority of cases the standard of care principles enunciated in ter Neuzen will result in a just determination of the common practice and thus the standard of care - as it has in this case. ${ }^{16}$ "Courts and juries do not have the necessary expertise to assess technical matters relating to the diagnosis or treatment of patients." ${ }^{17}$ It is important to note, however, that this general principle should only be applied to the medical or scientific component of a standard of care analysis ${ }^{18}$ - a point that Sopinka J. emphasizes throughout his judgment. There are often circumstances where the standard of care involves numerous, often conflicting, considerations. ${ }^{19}$ These factors may be difficult to separate into medical and non-medical components. Nevertheless, it is submitted that the trier of fact should strive to make such distinctions. For example, would the adequacy of a physician's allocation policy be a matter within the expertise of the medical profession or should it be considered a social policy which may be open to a broader examination by the judge or jury?

Clearly, the question of how and why a given medical procedure is performed is a matter to be determined by expert medical testimony, however, the manner in which medical resources are allocated is an issue which involves many factors including, perhaps, "common sense." It is this allocation component of the medical treatment decision which should not be left to the traditional formulation of medical custom. Merely because physicians allocate resources does not mean they necessarily have the type of expertise, as referred to in ter Neuzen, which would preclude the trier of fact from making an independent determination of the standard of care. This is not to say that the courts should be engaging in the active allocation of medical resources. Nevertheless, given the importance of such resources to society, the manner in which

Anderson, ibid. at 74. Quoted in ter Neuzen supra note 1 at 593, Sopinka J.

ter Neuzen, ibid. at 594.

However, what will be characterized as a "common sense" matter, and therefore open to the court's scrutiny, seems bound to emerge as another issue. For example, as a result of this case, courts may feel compelled to characterize something as a matter of "common sense" even though the medical profession views it as within their domain.

Supra note 1 at 592 . It has been suggested, however, that it is inappropriate to leave the issue of medical standards solely to the profession. See e.g. United Blood Services v. Quintana, 827 P.2d 509 at 520 (Colo. 1992):

If the standard adopted by a practising profession were to be deemed conclusive proof of due care, the profession itself would be permitted to set the measure of its own legal liability, even though that measure might be far below a level of care readily attainable through the adoption of practices and procedures substantially more effective in protecting others against harm than the self-decreed standard of the profession.

See also Klar, supra note 2 at 292 who notes: "[A]s clearly pointed out by Sopinka J. in ter Neuzen v. Korn, the issue in dispute must relate to a matter which is exclusively within the professional domain, and not within the trier of fact's own competence."

See J. Irvine, "The Physician's Duty in the Age of Cost Containment" (1994) 32 Manitoba Law Journal 345 at 346 where the author notes the numerous tensions - including economic concerns - which must be incorporated into the standard of care. See also Morreim, supra note 5. 
individual health care professionals implement, interpret and integrate allocation policies should remain open to the scrutiny of tort law. ${ }^{20}$

In ter Neuzen the Court did not have to address this type of allocation issue. However, there have been several recent cases where the courts have had to consider the impact of a cost containment policy on the treatment decisions of a defendant physician. In the British Columbia decision of Law Estate v. Simice, ${ }^{21}$ which was decided before the Supreme Court's decision in ter Neuzen, the trial judge was willing to consider how the pressures of budgetary cutbacks - a clearly non-medical consideration - impacted a physician's diagnosis of an aneurism. In this regard, Spencer J. stated as follows:

If it comes to a choice between a physician's responsibility to his or her individual patient and his or her responsibility to the Medicare system overall, the former must take precedence in a case such as this. The severity of the harm that may occur to the patient who is permitted to go undiagnosed is far greater than the financial harm that will occur to the Medicare system if one more CT procedure only shows the patient is not suffering from a serious medical condition. ${ }^{22}$

We see a similar examination in the Newfoundland case of McLean v. Carr ${ }^{23}-$ a case which also dealt with the withholding of a CT scan. In fact, in McLean the judge implies that information concerning the costs of providing CT scans may have influenced his decision concerning the appropriate standard:

The question is one of the cost effectiveness of precautions which could have been taken. It was allegedly too costly in 1987 to do a CT Scan on all head-injured patients. I was not, however, provided any evidence to establish that the cost would be prohibitive to scan, not all, but just patients whose skulls had considerable force applied and who had a resulting skull fracture. ${ }^{24}$

Courts can, as exemplified by Law Estate and McLean, distinguish between technical medical decisions and allocation policy. However, the impact of economic pressures may not always be so obvious and, as such, will require a careful analysis of the factors which result in the overall treatment decision. It is hoped that the strength of Sopinka

The idea that the courts have an active role in the monitoring of professions was suggested in Hajgato v. London Healih Assn., supra note 13 at 693:

[A] court has a right to strike down approved practice when common sense dictates such a result. No profession is above the law and the courts on behalf of the public have a critical role to play in monitoring and precipitating changes where required in professional standards. (1994), 21 C.C.L.T. (2d) 228 (B.C.S.C.) at 240, aff d [1996] 4 W.W.R. 672 (B.C.C.A.) [hereinafter Law Estate]. McLean elsewhere. Sce "Medical Malpractice and Cost Containment: The Canadian Experience" (1996) 6 Dispatches 4, where it is argued that these cases - which involve a conscious decision to ration - can be distinguished from cases which involve an actual scarcity of resources (See e.g. Bateman v. Doirin (1993), 18 C.C.L.T. 1 (N.B.C.A.)). 
J.'s conclusions regarding the formulation of the legal standard of care will not prevent judges and juries from engaging in such an analysis.

\section{B. ASSUMING THAT THE BEST INTERESTS OF THE PATIENT WILL PREVAIL}

Another rationale used by Sopinka J. for the application of this principle is that "the medical profession as a whole is assumed to have adopted procedures which are in the best interests of patients and are not inherently negligent." ${ }^{.25}$ One could argue that the current emphasis on cost containment has made the validity of this assumption somewhat less universal. While an allocation policy may be in the best interest of society as a whole, it may not be in the best interest of the individual patient. In other words, a physician may be integrating, either implicitly or explicitly, a societal goal such as economic efficiency - into his/her decision concerning the type of care which will be provided to a given patient. As a result, the patient may receive less care (and, perhaps, worse care) than he/she would receive if the patient's best interest was the only consideration. Balancing the needs of the individual against the needs of the whole health care system, while not a new phenomena, is becoming a more explicit (and increasingly necessary) aspect of modern medical practice. As such, the "best interest" assumption referred to by Sopinka J., although likely currently still valid, may need to give way to the more modest assumption that physicians will "do their best" - courts should feel free to carefully examine the manner in which physicians strive to do their best. $^{26}$

\section{CONCLUSION}

Admittedly, the conclusion that the principles from ter Neuzen should be applied carefully is hardly a bold recommendation. Nevertheless, given the protections that the medical profession has traditionally enjoyed in the realm of malpractice ${ }^{27}$ (not to mention the judicial attitude which has led to the evolution of those protections), ${ }^{28}$ and given the amount of restructuring which is currently occurring in the health care sector, the impact of the "ter Neuzen principle" could be significant - if only by making trial

2s Supra note 1 at 590 .

26. This is particularly so given the recent re-emphasis on the fiduciary nature of the physician/patient relationship - which arguably imposes a duty on the physician to do that which is the patient's best interest. See e.g. Norberg v. Wynrib, [1992] 2 S.C.R. 575; and McInerny v. MacDonald, [1992] 2 S.C.R. 138.

27 See e.g. G. Robertson, "Efficacy of the Medical Malpractice System: A Canadian Perspective" (1994) 3 Annals of Health Law 167 at 173 where the author notes:

[L]egal doctrines such as accepted medical practice, error in clinical judgment, and "two schools of thought" have given health care practitioners a considerable degree of protection. Recent case law indicates that these legal doctrines continue to have a significant impact on the outcome of medical malpractice litigation in Canada, with numerous cases being dismissed on the grounds that the defendant either acted in accordance with generally approved practice or committed only an excusable error of clinical judgment.

28 See e.g. see Lord Denning's comments in Roe v. Minister of Health, [1954] 2 Q.B. 66 (C.A.) at 86-87. 
judges hesitate in their analysis of all the factors that may be relevant to an allocation decision.

While the efficacy of tort law as a mechanism for the monitoring of the quality of health care is far from clear, ${ }^{29}$ it is one of the few mechanisms which patients have at their disposal. ${ }^{30}$ Trial judges, therefore, should not feel precluded from examining the non-medical factors relevant to the micro-allocation decisions of physicians. ${ }^{31}$ This is particularly so given that the influence that non-medical factors will have on treatment decisions will likely continue to intensify. Indeed, physicians would probably be among the first to admit that the current economic crunch is impacting their "medical decisions. ${ }^{.132}$ And while some may feel that it is inappropriate to place the burden of allocation decisions on the shoulders of physicians, that is where, at least from the perspective of the patient, it currently resides. As a result, the way in which physicians integrate the numerous non-medical factors into a final treatment decision should be open to scrutiny by a trier of fact.

See generally A Report of the Conference of Deputy Ministers of Health of the Federal/ProvincialTerritorial Review on Liability and Compensation Issues in Health Care: Liability and Compensation in Health Care (Toronto: University of Toronto Press, 1990).

See Canadian Bar Association Task Force on Health Care, supra note 5.

"Micro-allocation" refers to allocation decision which are made by physicians "at the bedside." Broader overall funding decisions, such as those made by health authorities, are called "macro allocation" decisions. Whether courts can review such macro decisions is another issue. See T. Caulfield, "Suing Hospitals, Health Authorities and the Government for Health-Care Allocation Decisions" (1994) 3 Health Law Review 7.

See e.g. The Medical Post 1995 National Survey of Doctors (Fall, 1995) at 69, where it is noted that almost half of the Canadian physicians surveyed felt that cost constraints have impacted their ability to prescribe the "drug of choice" $(49 \%)$ and has made it impossible to "admit [patients] who required in-patient care" (42\%). Similarly, in The Medical Post 1994 National Survey of Doctors (Fall, 1994) at 55-56, it was found that $72.4 \%$ of physicians thought that "[g]overnment intervention seriously interferes with the way in which [they] practice" and 70\% thought "[c]ost cuts such as hospital closures are impairing quality of health care." 